\section{Lessons from the covid-19 pandemic provide a blueprint for the climate emergency}

\author{
Synchronised global action is more effective than uncoordinated subnational responses
}

Renee N Salas affiliated faculty member

Two essential clinical principles have guided my practice as an emergency medicine doctor. First, I must use whatever information is available to predict and prepare for my patient's next potential crisis, such as identifying a back-up intubation plan from the start. The second is that treatments often need to be given in a certain window for optimal efficacy; timely intervention is critical.

In the covid-19 pandemic these two principles were ignored as the United States federal government dismissed early evidence that coronavirus was a global threat and failed to prepare the country-thus missing the optimal time window to intervene. As a result, the US has one of the highest death tolls in the world.

The US has also not pursued meaningful federal action on the climate crisis despite overwhelming evidence and harms to health through a frighteningly broad range of pathways-such as heatwaves, intensification of extreme weather, and vectorborne diseases. ${ }^{1}$ Indirectly, climate change also disrupts the delivery of healthcare and affects clinical practice. ${ }^{2}$ Although this already contributes to substantial morbidity and mortality, we still have time to minimise harm and save lives.

Three lessons have emerged from the pandemic that can provide a blueprint for the medical community's response to the climate crisis: health professionals must use their voices as trusted sources; prevention must be prioritised; and a rapid, coordinated global response is essential.

\section{Health professionals must use their voices as trusted sources}

We are in an era where science is often disregarded, even when it can guide timely, lifesaving decisions. In the case of covid-19, misinformation smothered the alarms, which is eerily reminiscent of the backlash climate scientists have been facing for decades. ${ }^{3}$ The repercussions are human suffering and lives lost.

Health professionals are serving as trusted voices in this pandemic, adding crucial narratives to the numbing statistics and neutralising dangerous misinformation. ${ }^{4}$ The same is needed for the climate crisis. Doctors are the most trusted source of information for climate change and health, and nurses are consistently the most trusted professionals. Our voices prioritise the health benefits of climate action, and our patient stories add the necessary context. ${ }^{5}$

\section{Prevention must be prioritised}

The covid-19 pandemic, just like the climate crisis, reinforces the essential need for resilient public health systems by exposing the limitations of medical treatments and the fragility of our healthcare systems. When covid-19 is ravaging the lungs of a patient, all I can offer is supportive care. Treatments for diseases exacerbated by the climate crisis can also be limited; treating an asthma exacerbation from rising pollen doesn't remove the cause.

Even further challenges arise if care delivery is compromised. For covid-19, this includes capacity concerns and the lack of vital resources like personal protective equipment, testing, and ventilators; for the climate crisis, unprecedented heatwaves and extreme weather jeopardise infrastructure, power grids, and supply chains. This places prevention as the utmost priority.

Preventive efforts in the pandemic to "flatten the curve," such as social distancing, have been critical as we optimise other public health resources and increase hospital resiliency. For the climate crisis, prevention means reducing carbon emissions and air pollution from the burning of fossil fuels. This intervention improves health, saves lives, and reduces burdens on the healthcare system. ${ }^{67}$ If this isn't enough motivation, reducing greenhouse gas emissions can also create jobs and be cost effective. ${ }^{89}$ Thus, the medical community must advocate for prevention here just as it has in the pandemic.

\section{A rapid, coordinated global response is essential}

This pandemic serves as a poignant reminder of just how interconnected our world is. We are united in a shared vulnerability to this invisible pathogen, just as we are for the unseen greenhouse gases. Both crises are exacerbating underlying inequalities as vulnerable communities-from subpopulations to entire countries-bear the brunt of harm. Mismanagement of the pandemic in one country threatens lives in another, just as greenhouse gases can exert their deadly effects halfway around the globe.

Synchronised global and national action is much more effective than uncoordinated subnational responses, whether for ventilator procurement or reducing reliance on fossil fuels. Urgent, coordinated responses provide the optimal path out of both the global pandemic and the climate crisis, using a multidisciplinary approach that includes health professionals. $^{10} 11$ 
The importance of the medical community, and our inherent responsibilities as public servants, is perhaps the clearest it has been in modern day. Yet even as I deal with the covid-19 pandemic on the front line, my guiding principles compel me to continue to strive for preventive action on climate. Although the US failed to act in January on the pandemic, we are still in the "January" equivalent for the climate crisis. These lessons can provide a blueprint to mobilise health professionals to save lives before it is too late.

Conflicts of Interest: I have read and understood BMJ policy on declaration of interests and have no competing interests to declare.

Provenance and peer review: Commissioned, not peer reviewed.

1 Watts N, Amann M, Arnell N, etal. The 2019 report of The Lancet Countdown on health and climate change: ensuring that the health of a child born today is not defined by a changing climate. Lancet 2019;394:1836-78. doi: 10.1016/S0140-6736(19)32596-6 pmid: 31733928

2 Salas RN. The climate crisis and clinical practice. N Engl J Med 2020;382:589-91. doi: 10.1056/NEJMp2000331 pmid: 32053295

3 Rutschman AS. Mapping misinformation in the coronavirus outbreak. Health Affairshttps://www.healthaffairs.org/do/10.1377/hblog20200309.826956/full/

4 Dahlstrom MF. Using narratives and storytelling to communicate science with nonexpert audiences. Proc Natl Acad Sci USA 2014:111(Supplement 4):13614-20. doi: 10.1073/pnas.1320645111 pmid: 25225368

5 Milner J, Hamilton I, Woodcock J, etal. Health benefits of policies to reduce carbon emissions. BMJ2020;368:16758. doi: 10.1136/bmj.16758 pmid: 32229476

6 Haines A, Ebi K. The Imperative for Climate Action to Protect Health. N Engl J Med 2019;380:263-73. doi: 10.1056/NEJMra1807873 pmid: 30650330

7 Patz JA, Stull VJ, Limaye VS. A low-carbon future could improve global health and achieve economic benefits. JAMA 2020;323:1247-8. doi: 10.1001/jama.2020.1313 pmid: 32108863

8 The employment impact of climate change adaptation. https://www.ilo.org/wcmsp5/groups/public/--ed_emp/documents/publication/wcms_645572.pdf

9 Markandya A, Sampedro J, Smith SJ, etal. Health co-benefits from air pollution and mitigation costs of the Paris Agreement: a modelling study. Lancet Planet Health 2018;2:e126-33. doi: 10.1016/S2542-5196(18)30029-9 pmid: 29615227

10 Kickbusch I, Leung GM, Bhutta ZA, Matsoso MP, Ihekweazu C, Abbasi K. Covid-19: how a virus is turning the world upside down. BM/2020;369:m1336. doi:10.1136/bmj.m1336 pmid: 32245802

11 Karliner J. The most important global public health agreement of the century. BMJ2015;351:h6878. doi: 10.1136/bmj.h6878 pmid: 26681606

This article is made freely available for use in accordance with BMJ's website terms and conditions for the duration of the covid-19 pandemic or until otherwise determined by BMJ. You may use, download and print the article for any lawful, non-commercial purpose (including text and data mining) provided that all copyright notices and trade marks are retained. 